\title{
Geospatial Analysis of Road Traffic Accidents, Injuries and Deaths in Nigeria
}

\author{
Tolulope Osayomi and Abidoun Ayooluwa Areola
}

Received: 01042015 / Accepted: 15042015 / Published online: 30062015

(c) 2015 Faculty of Geography UGM and The Indonesian Geographers Association

\begin{abstract}
RTAs in Nigeria are very high and have become progressively important because of their heavy health and financial burden. The few geographic studies on RTAs in Nigeria are limited to their mere spatial distribution and associated risk factors, with very little attention given to their spatial clustering patterns and the detection of hotspots. With the aid of Global Moran's I and Local Getis, the study found some evidence of significant positive spatial autocorrelation, and consistent clustering of RTAs, RTIs and RTDs in the southwest from 2002 to 2007 which suggested the presence of an accident belt in the southwestern region, which has been accounted by poor road infrastructure, relatively high level of economic development and high vehicular movements. The study recommends the deployment of road safety officials to the accident belt, strict enforcement of safety belts and helmets, and periodic road maintenance.
\end{abstract}

Keywords: road traffic accidents, spatial autocorrelation, poor road infrastructure, G.I.S., accident belt, Nigeria

\begin{abstract}
Abstrak RTA di Nigeria yang sangat tinggi dan telah menjadi semakin penting karena kesehatan berat dan beban keuangan. Studi geografis beberapa di RTA di Nigeria terbatas faktor distribusi spasial dan risiko yang terkait hanya mereka, dengan sangat sedikit perhatian yang diberikan kepada pola pengelompokan spasial dan deteksi hotspot. Dengan bantuan Global Moran I dan lokal Getis, studi ini menemukan beberapa bukti autokorelasi spasial yang signifikan positif, dan clustering konsisten RTA, ISR dan RTDs di barat daya 2002-2007 yang menunjukkan adanya sebuah sabuk kecelakaan di wilayah barat daya, yang telah dicatat oleh infrastruktur jalan yang buruk, relatif tingginya tingkat pembangunan ekonomi dan gerakan kendaraan yang tinggi. Penelitian ini merekomendasikan penyebaran pejabat keselamatan jalan untuk sabuk kecelakaan, penegakan ketat sabuk pengaman dan helm, dan pemeliharaan jalan berkala.
\end{abstract}

Kata kunci: kecelakaan lalu lintas jalan, autokorelasi spasial, infrastruktur jalan yang buruk, GIS, sabuk kecelakaan, Nigeria

\section{Introduction}

Road traffic accidents (RTAs) are unquestionably one of the many scourges afflicting the world with a greater impact on developing countries [World Health Organization, 2013]. Over 1.24 million die as a result of RTAs annually in the world [World Health Organization, 2013] while road traffic injuries (RTIs) are one of the three principal causes of death worldwide for those within the age group 5-44 years, many of whom are children, adolescents and young adults [World Health Organisation, 2010]. Likewise, RTAs hold the third position on the list of causes of mortality in Africa [Chidoka, 2009].

Like in many parts of the world, RTAs and RTIs are very high in Nigeria and have become progressively important because of their heavy health and financial burden. Every year, the country loses “... 5,000 lives with an estimated economic cost of about 65 billion naira (or USD 406,250,000 @ USD = N160) per year" [Arosanyin, 2008 cited in Ipingbemi and Dandy, 2011]. Because of these adverse consequences, this issue has drawn keen attention from both academic and policy

Tolulope Osayomi and Abidoun Ayooluwa Areola Department of Geography, University of Ibadan, Nigeria. Email: osayomi@yahoo.com circles who have tried to come up with RTA prevention and reduction strategies. Despite these efforts including the country's recent national action plan on road safety, the Safe Road initiative,which largely derived from the United Nations' Decade of Action for Road Safety (2011-2020) to "reduce road traffic crashes and injuries by 50 percent in 2020" [FRSC, 2012], RTAs, RTIs and RTDs still remain major causes of anxiety.

As in many other academic disciplines, RTAs have been a theme of geographical research in Nigeria, although actual studies have been few and far between. A review of the few past studies such as Gbadamosi [2005], Aderamo [2012] and Osayomi [2013] indicate significant geographical variations in RTAs, RTIs and road traffic deaths (RTDs) in Nigeria while Jegede [1988] and Atubi and Onokala [2009] performed state level analysis of RTAs in the Old Oyo state and Lagos state respectively. In detail, Gbadamosi [2002]'s study conducted space-time study of accidents from 1970-1995, and discovered that federal roads and the area of state were contributory factors. Aderamo [2012] described the spatial patterns of road traffic causalities and deaths in Nigeria from 2004 to 2007, and used regression modelling to identify significant 
contributors. Like the others, there were noticeable spatial variations in casualties and deaths with motor vehicle injuries and deaths were positively related to population size of the state and length of roads. Conversely, Osayomi [2013] analysed regional patterns of RTAs in the country and found that there was a South-North gradient in their occurrence. In addition, it was found that poor road infrastructure was largely a significant factor in RTAs in Nigeria as a whole. Clearly, these previous works not only provided preliminary evidence of spatial variations of RTAs, RTIs and RTDs but also outlined areal associations between RTAs and the possible risk factors. From the foregoing review, very little is obviously known about the nature and strength of spatial clustering of RTAs and their local spatial variations.

It is very important to note that a study of this nature is hard to carry out without the aid of rigorous Geographical Information Systems (GIS) based spatial analysis. Geospatial techniques are widely used in analyzing the spatial distribution of phenomena so as to determine their nature. In particular, they give answers to key questions such as (i) are there unusual clusters of phenomena and (ii) which areas have hotspots or coldspots of a given phenomenon in question? [Djukpen, 2010]. They have been widely applied in the areas of disease ecology [Samuelsson and Lofman, 2004; Portnov et al. 2009; Michmi and Wimberly, 2010; Djukpen, 2010], crime mapping [Lane and Sui, 2010], regional development [Yu and Wei, 2008], health services [Zhang et al. 2011] and older adult migration [Sharma, 2012].

In the area of accident analysis, GIS analysis has become increasingly helpful because it has shed more light on the nature of the spatial pattern of RTAs. For instance, Loo [2013] employed GIS to validate the spatial variables of the crash databases in Hong Kong from 1993 to 2004. In Lugo province of northwest Spain, Rodriguez-Morales et al. [2013] analysed the daily, weekly and seasonal spatiotemporal patterns of car crashes involving wild boar and roe deers in the 20062010 period. Erdogan [2009] applied geographically weighted regression (GWR) and spatial autocorrelation to the investigation of inter provincial differences in traffic accidents and mortality in Turkey. Pulugurtha et al. [2007] in their study of spatial patterns of pedestrian crashes, used GIS to identify high pedestrian crashes zones. Lastly, Andersson [2009] used GIS and kernel density estimation to analyse the spatial pattern of injury related road accidents in London, UK.

From the above examples, it is clear that geospatial technology has proven to be an effective tool for accident control and road safety management. Therefore, this study not only seeks to contribute to the geographical study of RTAs, RTIs and RTDs in Nigeria, but also to demonstrate the usefulness of geospatial analysis in helping the country's transport professionals and policy makers to design geographically sensitive and evidence based policies and strategies to reduce the high incidence of RTAs, RTis and RTDs in the country.

Specifically, the central objective of the study is to examine, if any, the national and local spatial patterns of RTAs, RTIs and RTDs in Nigeria. In order to do this, the analyses were done at the state level for Nigeria using geospatial techniques. To achieve the above objective, three specific research questions were addressed in the study:

1. What is the nature of the geographical distribution of RTAs, RTIs and RTDs in Nigeria in the period from 2002 to 2007 ?

2. Were they evenly distributed or clustered in space?

3. Where are the hotspots of RTAs, RTIs and RTDs in Nigeria?

The next section outlines the data sources of the study, and discusses the set of geospatial and statistical techniques that were used to analyze and describe the general pattern of RTAs, RTIs and RTDs and to detect the location of hotspots. Section three provides the results of analysis. The final section provides a discussion of the results and conclusion.

\section{The Methods}

Data on RTAs, RTIs and RTDs were culled from the Annual Abstract of Statistics 2009 published by the National Bureau of Statistics, Nigeria (available at http:// www.nigerianstat.gov.ng). This publication provides information on incidence of road traffic accidents, injuries and deaths from year 2002 to 2007 for the thirty six states of Nigeria and the Federal Capital Territory. The data provided include year, state of occurrence, number of accidents, number of injuries and number of deaths.

The ArcGIS software version 9.3 was used to map the number of RTAs, RTIs and RTDs in order to visualize spatial patterns. A series of maps for RTAs, RTIs and RTDs was produced for each of the years within the study period. The data were subjected to geospatial analysis using two different approaches as described below. To determine the degree of spatial clustering, and test for the presence of RTA, RTI and RTD clusters of accidents, local and global indicators of association were used. They are the Global Moran's I and the Getis $\left(\mathrm{Gi}^{\star}\right)$ statistic.

The Global Moran's I test was performed to measure degree of spatial clustering of accidents/injuries/deaths i.e. whether their occurrence in space is clustered or not, for each year in the specified time period. This statistical tool assessed the spatial distribution by testing the null hypothesis, which states that there is no significant spatial clustering of RTAs, RTIs and RTDs. Rejection of the null hypothesis, it would indicate the existence of spatial autocorrelation would for instance mean that spatial autocorrelation means RTA, RTI and RTD rates in a given state are significantly related to those in contiguous states. This certainly conforms to 
Tobler's first law of geography which succinctly states that "everything is related to everything else but near things are more related than distant things" [Tobler, 1970].

Spatial autocorrelation is of three forms. Positive spatial autocorrelation describes a situation in which like values cluster together. Negative spatial autocorrelation indicates that there are observations with dissimilar values, for example, states with low rates are close to those with high rates or vice versa. Its index value varies between -1 to 0 to 1 , where positive values (between 0 and 1 ) indicate a positive spatial correlation; negative values (between -1 and 0 ) suggest a negative spatial association, and values very close to or equal to 0 specify the absence of spatial autocorrelation.

The Global Moran 's I has a limitation which lies in the fact it does not show the location of spatial clusters or, to put it simply, it does not show where a given phenomenon is spatially concentrated. In order to make up for this shortcoming in the use of Global Moran's I, this study applied the local Getis $\left(\mathrm{Gi}^{*}\right)$ statistic with a view to detecting spatial clusters.

The Getis $\left(\mathrm{Gi}^{*}\right)$ statistic is a spatial cluster analysis tool used to identify unique local spatial patterns of a given phenomenon. In this study, it was used to reveal RTA, RTI and RTD hotspots. The presence of hotspot areas was determined using Z-score values. High and positive clusters with $\mathrm{Z}$ score values less than 1.96 indicate the presence of coldspots while values greater 1.96 are indicative of areas of hotspots. For the purpose of this study, only hotspots were identified for each year. The results for each calendar year were compiled with a view to discerning temporal changes in the locations of hotspots of RTAs, RTIs and RTDs over the study period.

\section{Results and Discussion}

There were 114,100 RTAs, 95,793 RTIs and 50,844
RTDs recorded in Nigeria from 2002 to 2007. The yearly distribution of RTAs, RTIs and RTDs is shown in Figure 1. As illustrated in Figure 1, the highest numbers of RTAs and RTIs were recorded in the year 2002 while the frequency of RTDs reached its peak in 2007. From the spatial perspective, there are noticeable geographic variations in RTAs, RTIs and RTDs as shown in Figures 2- 19.

Figures 2 to 6 show the spatial distribution of road traffic accidents from 2002 to 2007. On the average, the number of cases was higher in the south than in the north. In 2002, the map reveals that accident cases were higher in the south than in the north. In the south, the southwestern states of Oyo, Ogun, Lagos; the south south states of Edo and Delta, and the southeast state of Enugu exhibited higher accident rates. The northern states generally reported lower cases of accidents except Benue, Kano and Katsina. By 2003, the accident burden shifted to Osun and Ondo states in the southwest and to Cross River state in the south south region. Relatively speaking, the northern states still reported lower numbers; however Kano and Benue states still remained accident clusters, but there was a new cluster found in Plateau state. In 2004, the accidents numbers were reduced drastically with a southwestern cluster centered on Oyo, Osun and Lagos states, and isolated clusters in Kano and Plateau states. Road traffic accidents aggressively re-emerged in 2005 and spread rapidly thereafter throughout the country. In the north, the spread was rather gradual while the accident numbers appeared to have increased in the southwestern cluster. This pattern remained consistent in 2006 and 2007. The results of spatial autocorrelation for the three events are summarized in Table 1. As shown below, there was a significant spatial clustering of accidents in 2003 ( $\mathrm{I}=2.33$; p < 0.05) and 2004 ( $\mathrm{I}=$ $2.8 ; \mathrm{p}<0.05)$

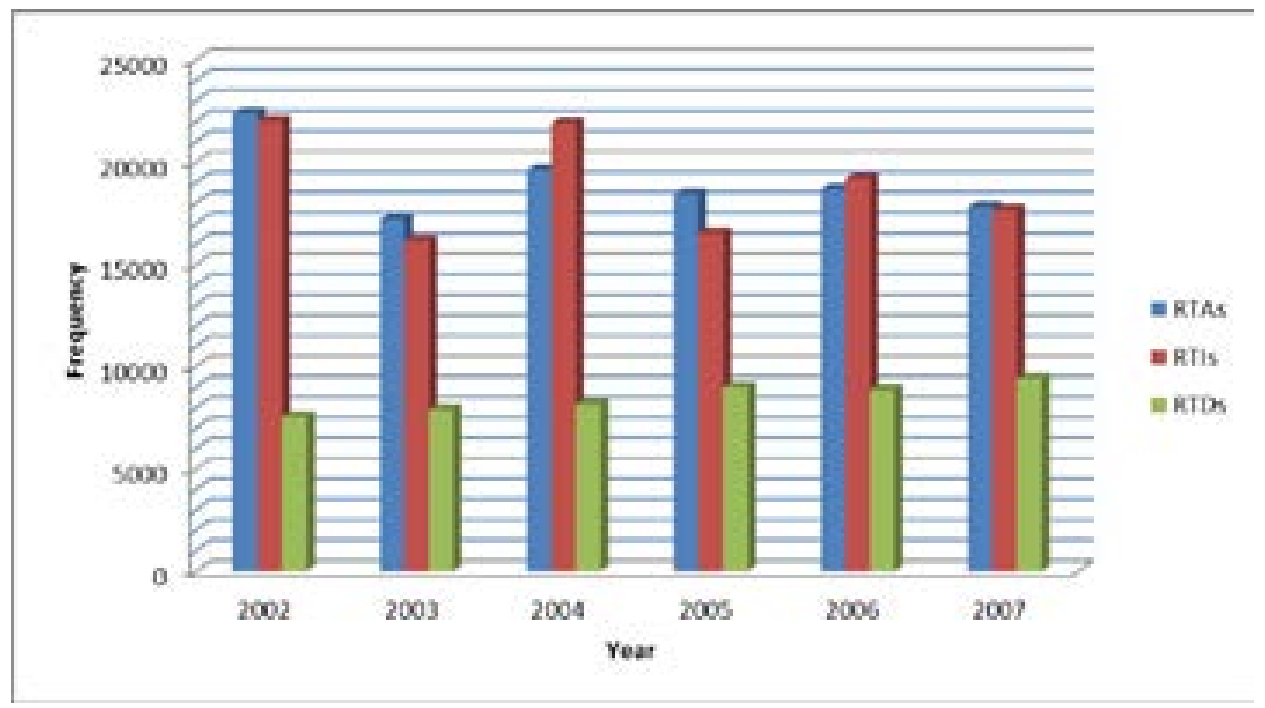

Source: Annual Abstract of Statistics (2009)

Figure 1. Annual distribution of RTAs, RTIs and RTDs from 2002 to 2007. 
Table 1. Moran's I values for RTAs

\begin{tabular}{|c|c|c|c|c|}
\hline Year & Index value & Z scores & $\mathrm{p}$ value & Remark \\
\hline 2002 & 0.09 & 1.63 & $>0.05$ & $\begin{array}{l}\text { Somewhat } \\
\text { clustered }\end{array}$ \\
\hline 2003 & 0.18 & 2.33 & $<0.05$ & Clustered \\
\hline 2004 & 0.21 & 2.8 & $<0.05$ & Clustered \\
\hline 2005 & 0.04 & 0.72 & $>0.05$ & $\begin{array}{l}\text { Somewhat } \\
\text { clustered }\end{array}$ \\
\hline 2006 & -0.02 & 0.08 & $>0.05$ & $\begin{array}{l}\text { Somewhat } \\
\text { clustered }\end{array}$ \\
\hline 2007 & -0.01 & 0.2 & $>0.05$ & Random \\
\hline
\end{tabular}

On the whole, RTIs patterns only follow a SouthNorth trend but also appear to be dynamic from 2002 to 2007 (Table 2), however, some states were spatially static (see figures 7 to 13). There were distinct regional variations in RTIs with higher rates concentrated in the southwestern states (Oyo, Lagos and Ogun) and a few states in Northwestern, South Southern and North central Nigeria as at 2002. The spatial pattern remained more or less the same in 2003. But, in 2004, the clustering of road traffic injuries expanded to include some new states in the southwest and northwest. Figure 11 shows a gradual decline in the rates and a spatial dispersion in 2005. Spatial dispersion became very pronounced in 2006. By 2007, road traffic injuries appeared to have suddenly increased, with very high rates in Ogun, Benue and Kaduna states. There was no evidence of spatial autocorrelation for road traffic injuries except for 2002 ( $\mathrm{I}=0.17, \mathrm{p}<0.05)$. The Moran's I statistic results suggest non randomness in the overall spatial pattern of road traffic accidents in most years.

Table 2. Moran's I values for RTIs

\begin{tabular}{rrrrl}
\hline Year & Index value & Z scores & P value & Remark \\
\hline 2002 & 0.17 & 2.43 & $<0.05$ & Clustered \\
2003 & 0.1 & 1.39 & $>0.05$ & $\begin{array}{l}\text { Somewhat } \\
\text { clustered }\end{array}$ \\
2004 & 0.05 & 0.86 & $>0.05$ & $\begin{array}{l}\text { Somewhat } \\
\text { clustered }\end{array}$ \\
2005 & 0.05 & 0.86 & $>0.05$ & $\begin{array}{l}\text { Somewhat } \\
\text { clustered }\end{array}$ \\
2006 & -0.05 & -0.2 & $>0.05$ & Random \\
2007 & -0.03 & 0.02 & $>0.05$ & Random \\
\hline
\end{tabular}

Similarly, RTDs exhibited south-north differences. In 2002, RTD rates were generally low with notable exceptions in the southwestern (Oyo, Ogun and Lagos) and northwestern (Kano and Katsina) clusters. The southwestern and northwestern clusters persisted in 2003 but, in addition, two other noticeable clusters emerged in Benue and Borno states. In 2004, the RTD increased and spread from the core into states like Osun, Ondo in the southwest, and to Edo, Delta and Cross
River states with Rivers State emerging as a new isolated cluster in the south south. In the northwest, RTD clusters moved beyond the dominant northwestern core into some parts of the North central e.g. Plateau state, and Northeast e.g. Bauchi State. In 2005, the spatial pattern of RTDs appeared to be dispersed with isolated clusters in North central region particularly the Federal Capital Territory, Benue and Plateau states. In the southwest, RTDs intensified in Osun state. By 2006, rates were low throughout the country. Kaduna was the only state with high RTDs. The pattern did not appear to have changed in 2007 (see figures 13 to 19). As shown in Table 3, there was significant clustering of RTDs in 2002 and 2004.

Table 3. Moran's I values for RTDs

\begin{tabular}{|c|c|c|c|c|}
\hline Year & Index value & $Z$ scores & $P$ value & Remark \\
\hline 2002 & 0.19 & 2.76 & 0.01 & Clustered \\
\hline 2003 & 0.1 & 1.39 & $>0.05$ & $\begin{array}{l}\text { Somewhat } \\
\text { clustered }\end{array}$ \\
\hline 2004 & 0.29 & 3.48 & 0.01 & Clustered \\
\hline 2005 & 0.08 & 1.15 & $>0.05$ & $\begin{array}{c}\text { Somewhat } \\
\text { clustered }\end{array}$ \\
\hline 2006 & -0.02 & 0.08 & $>0.05$ & Random \\
\hline 2007 & -0.14 & -1.48 & $>0.05$ & $\begin{array}{l}\text { Somewhat } \\
\text { dispersed }\end{array}$ \\
\hline
\end{tabular}

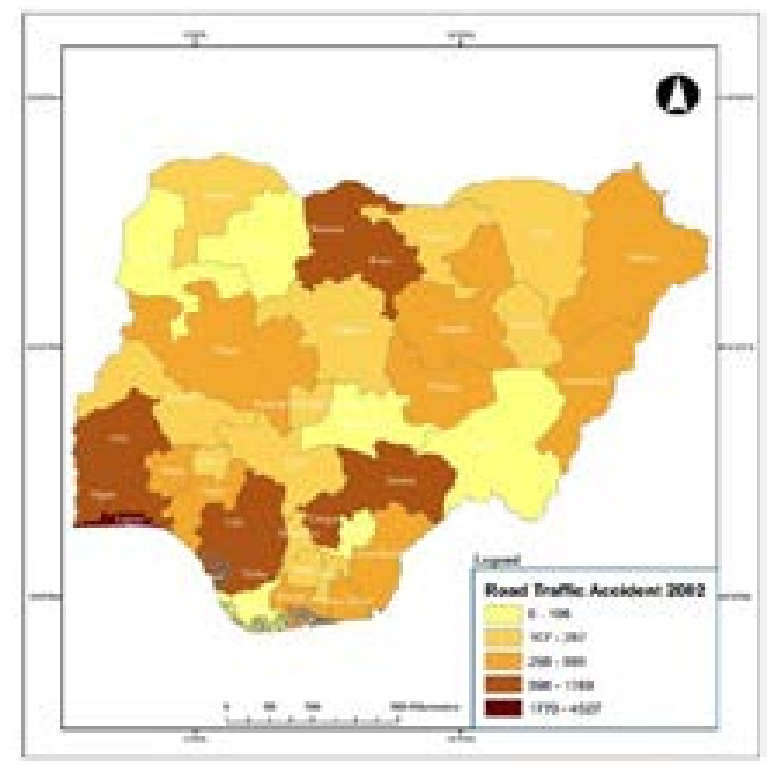

Figure 2. Road traffic accidents in 2002 


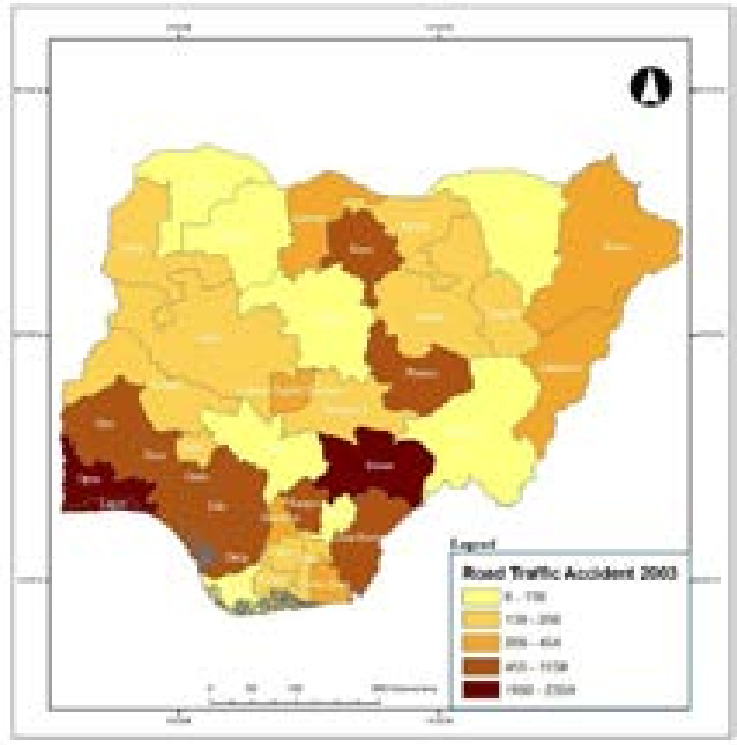

Figure 3. Road traffic accidents in 2003

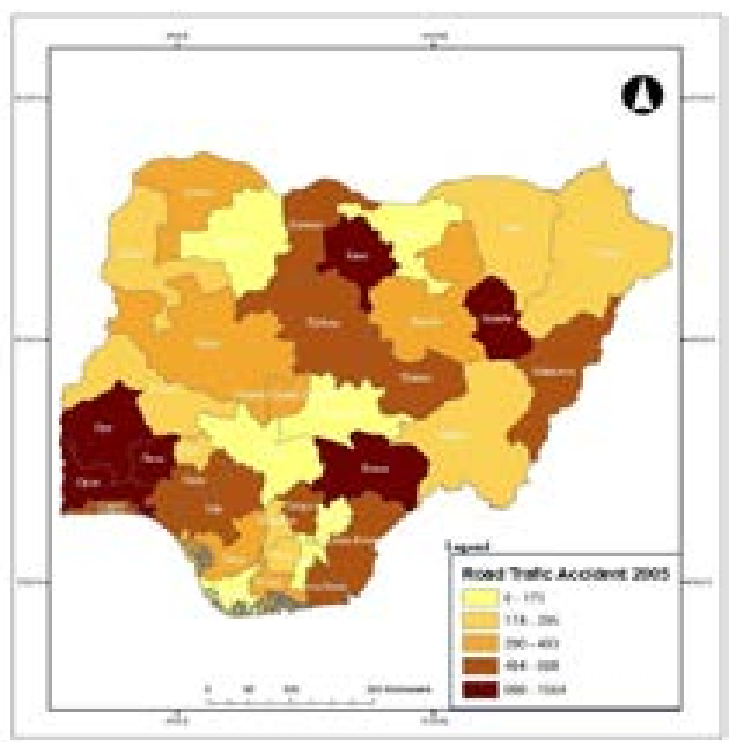

Figure 5. Road traffic accidents in 2005

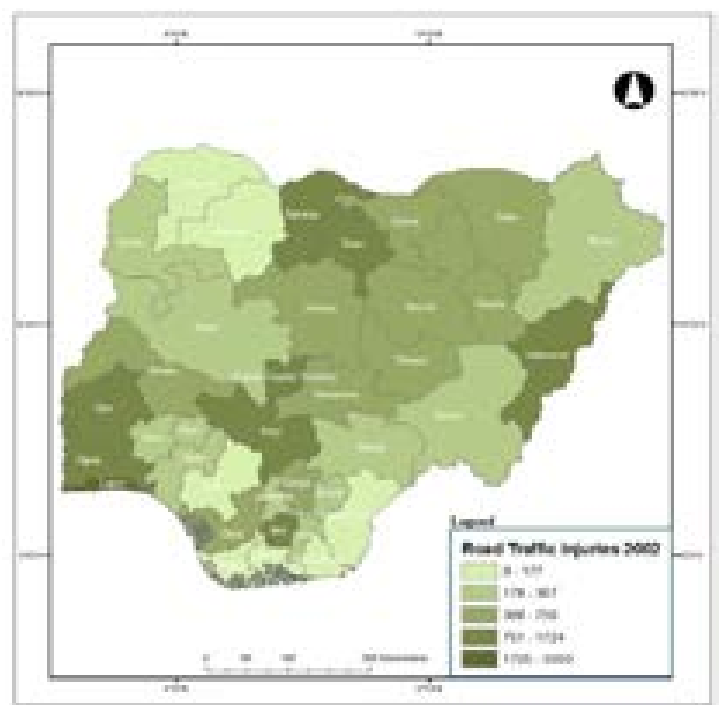

Figure 8. Road traffic injuries in 2002

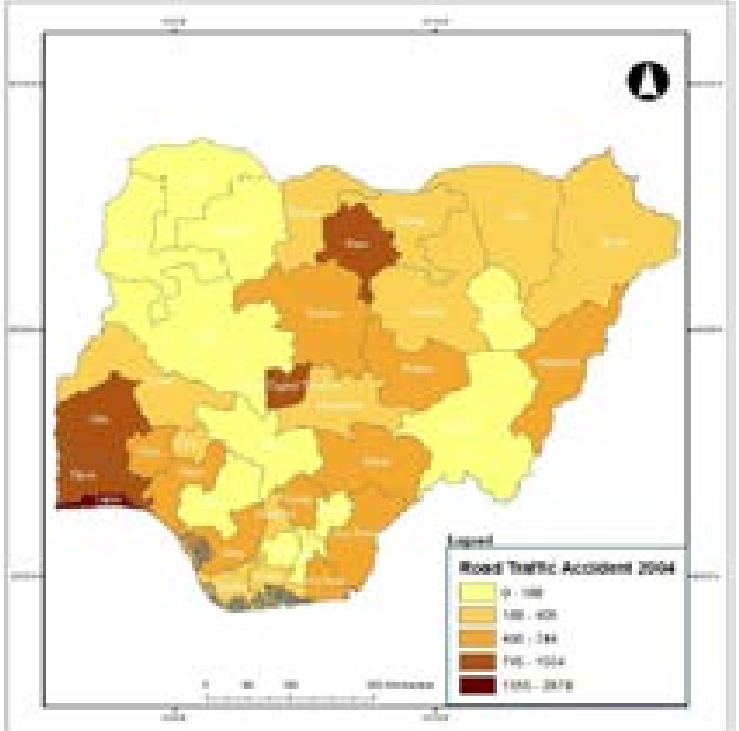

Figure 4. Road traffic accidents in 2004

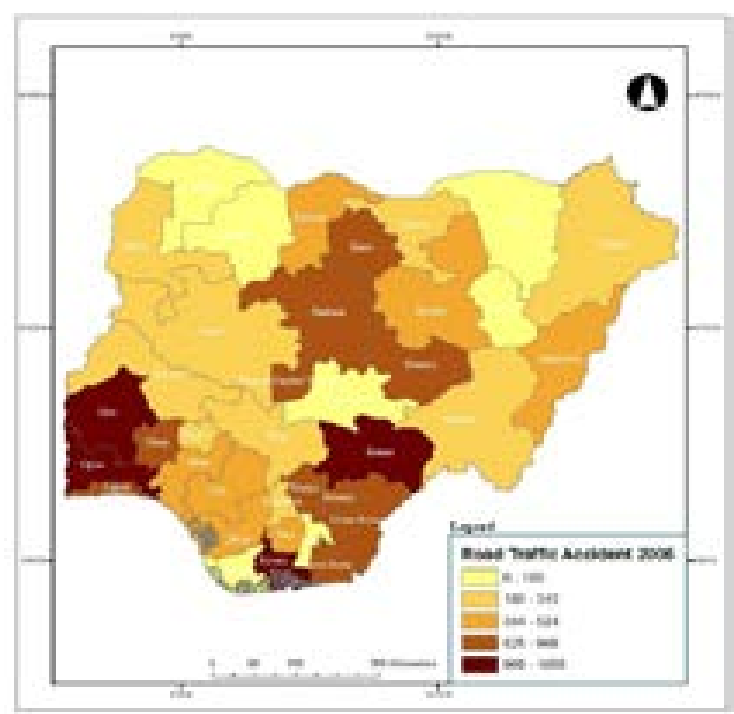

Figure 6. Road traffic accidents in 2006

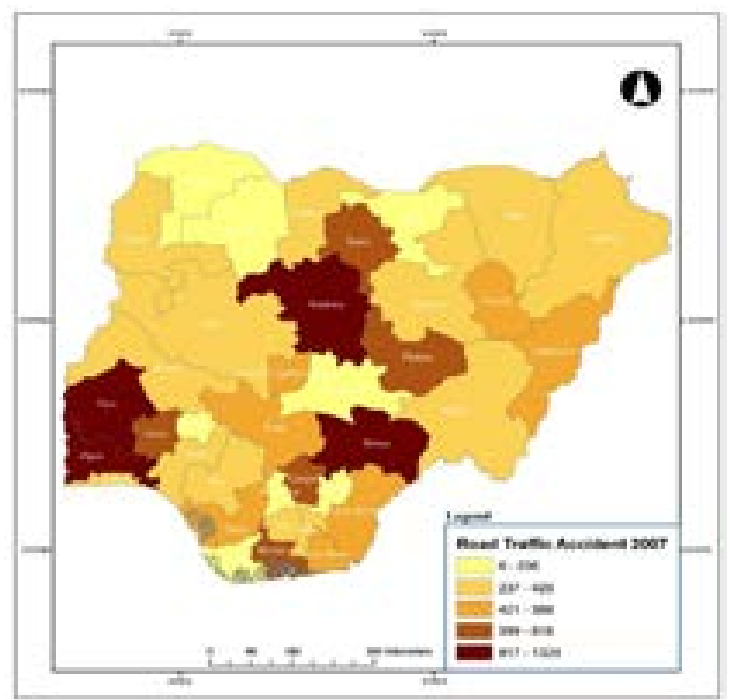

Figure 7. Road traffic accidents in 2007 


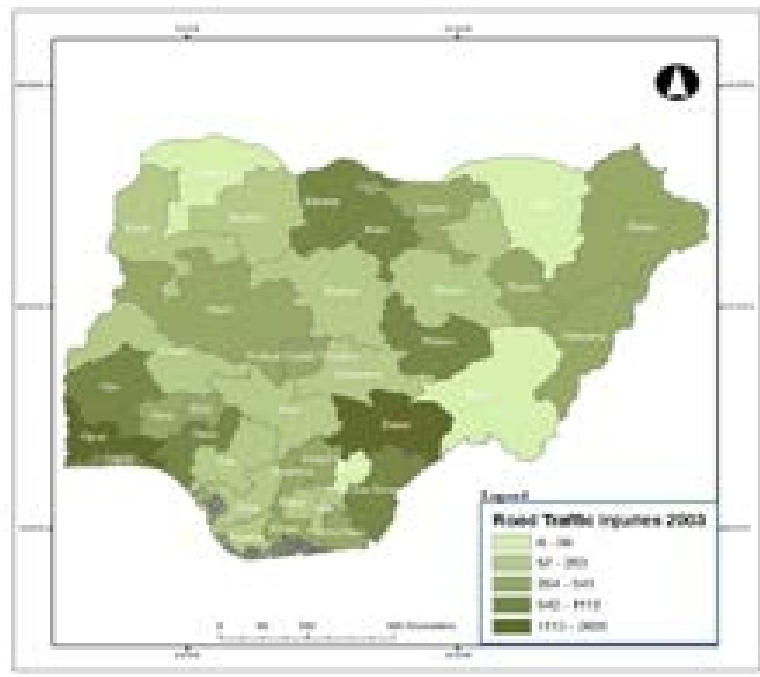

Figure 9. Road traffic injuries in 2003

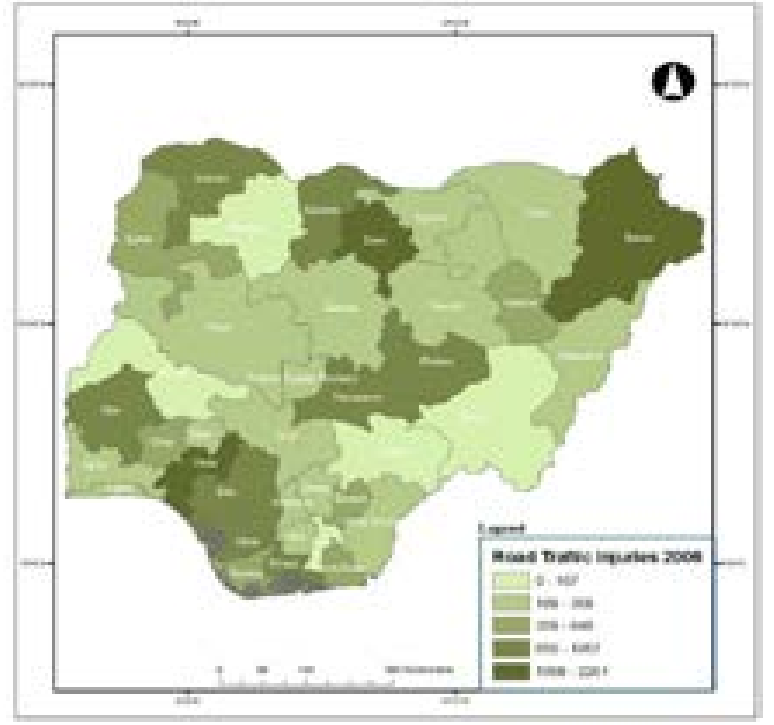

Figure 12. Road traffic injuries in 2006

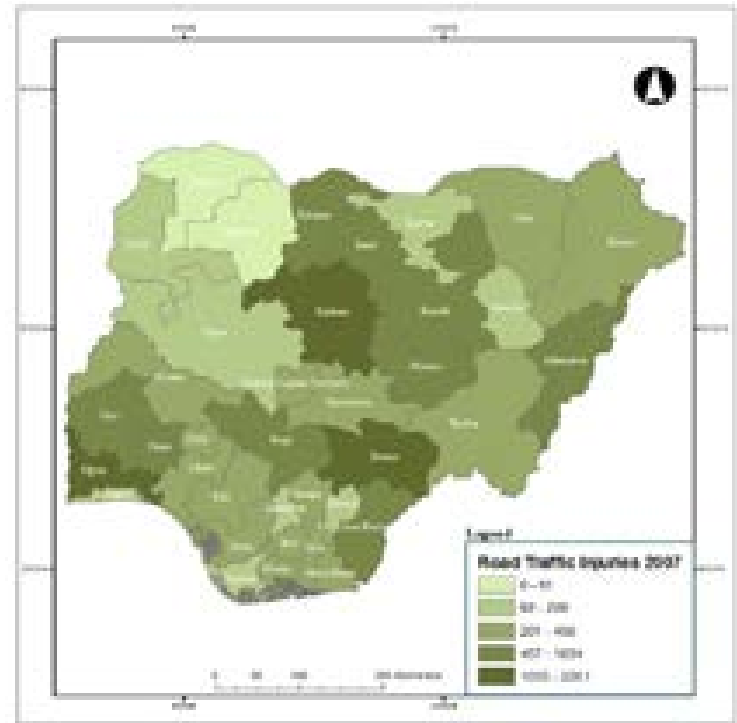

Figure 13. Road traffic injuries in 2007

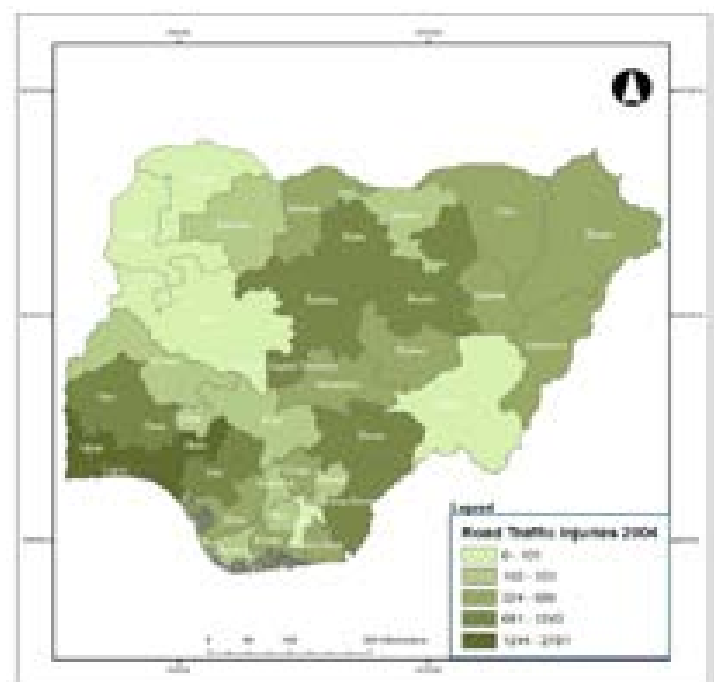

Figure 10. Road traffic injuries in 2004

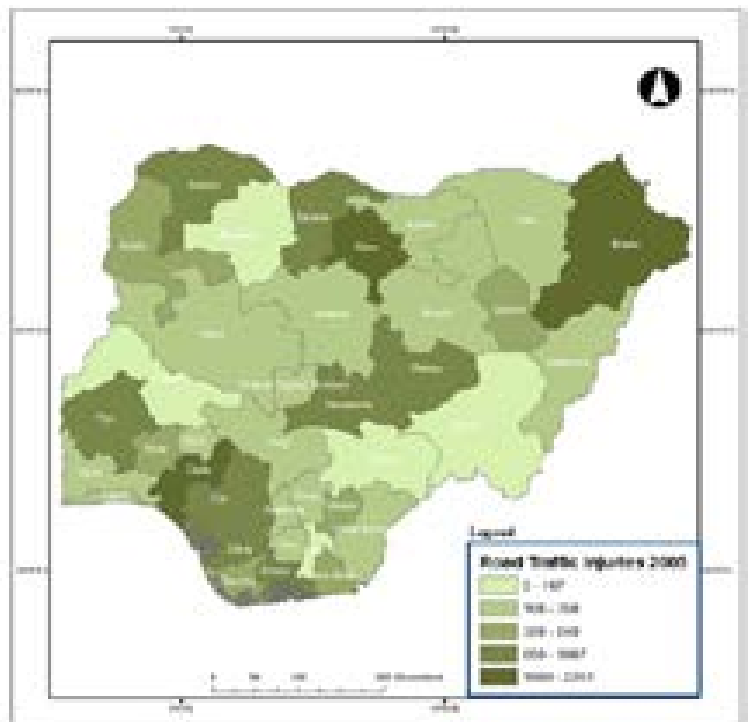

Figure 11. Road traffic injuries in 2005

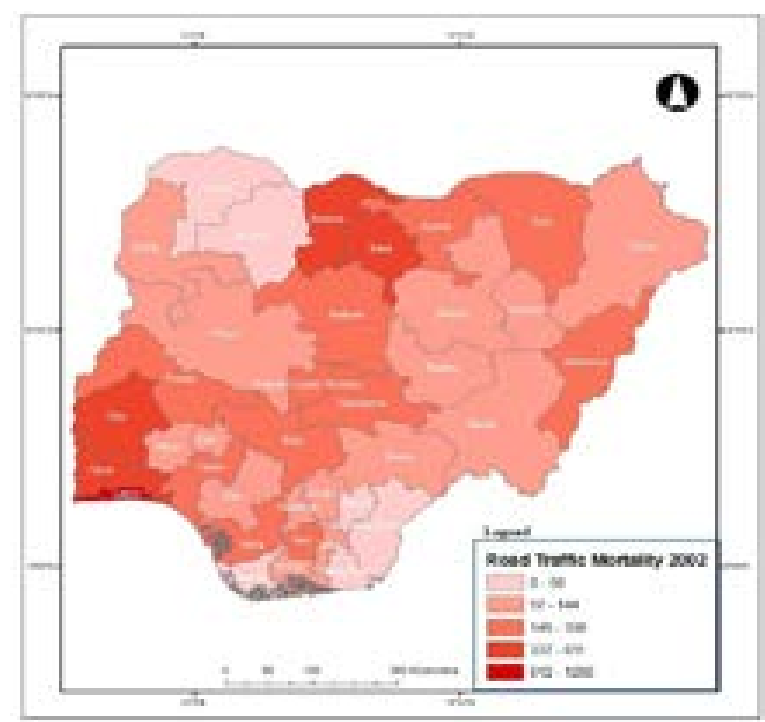

Figure 14. Road traffic deaths in 2002 


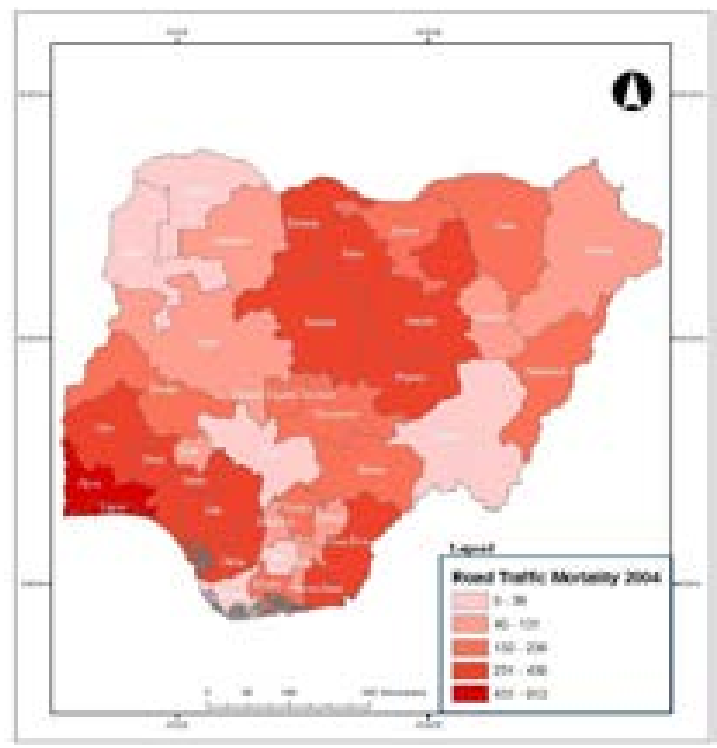

Figure 16. Road traffic deaths in 2004

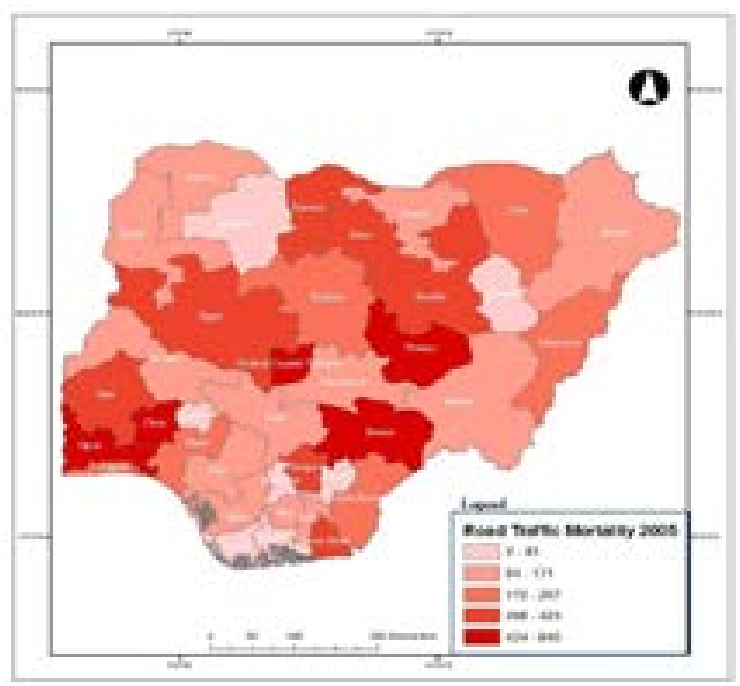

Figure 17. Road traffic deaths in 2005

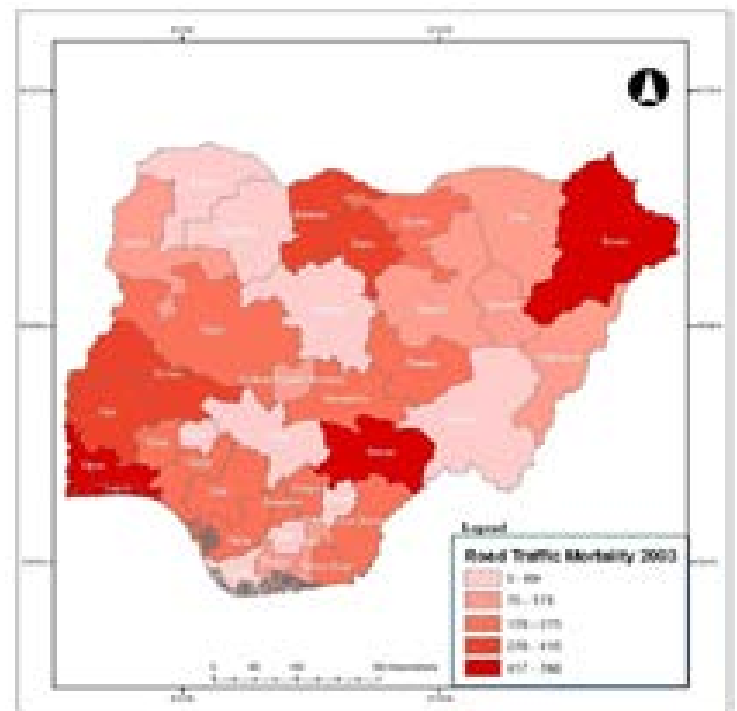

Figure 15. Road traffic deaths in 2003

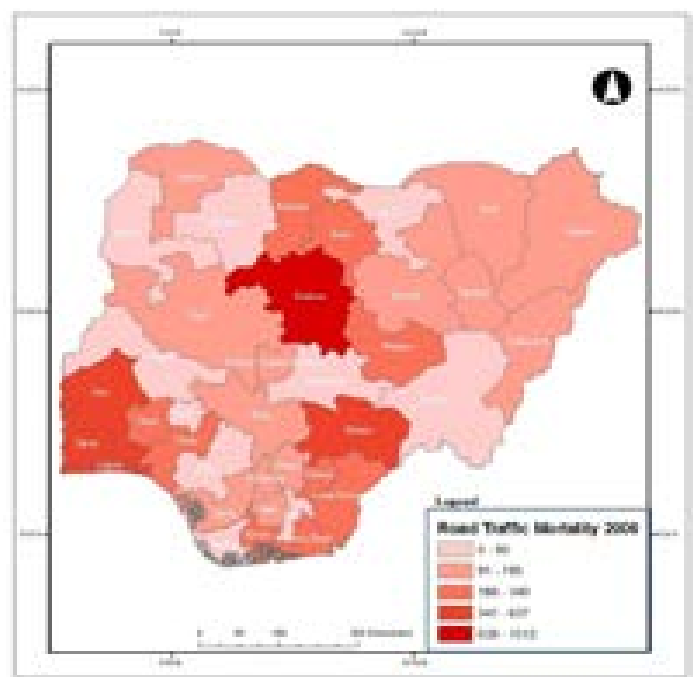

Figure 18. Road traffic deaths in 2006

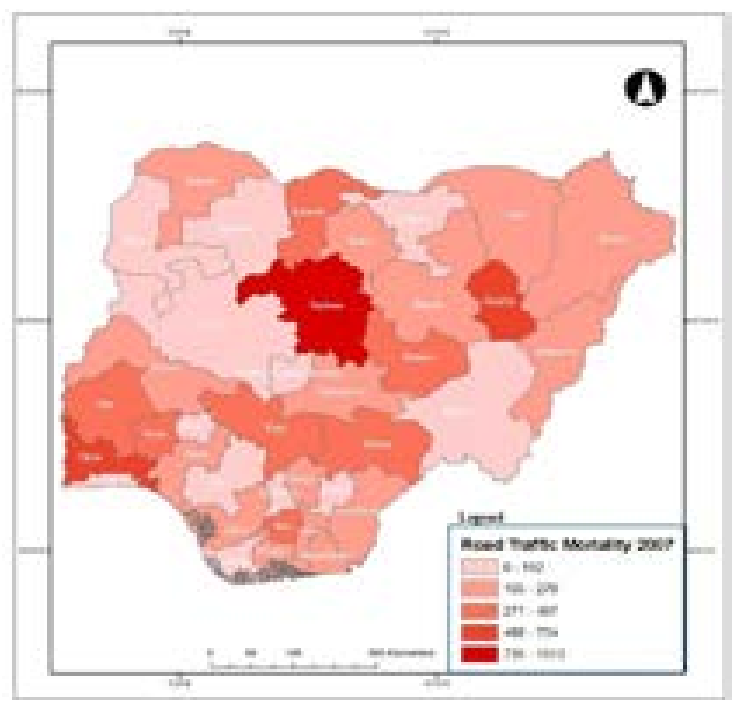

Figure 19. Road traffic deaths in 2007 
As shown in the Table 4, significant clusters of high values were detected for RTAs throughout the study years. The southwest cluster centered particularly on Lagos, Ogun, Oyo states, persisted throughout the period 2002 - 2007.

Table 4. Hotspots for RTAs

\begin{tabular}{|c|c|c|}
\hline Year & State & Gi Index value* \\
\hline 2002 & $\begin{array}{l}\text { Lagos } \\
\text { Ogun }\end{array}$ & $\begin{array}{l}4.217630 \\
3.119860\end{array}$ \\
\hline 2003 & $\begin{array}{l}\text { Lagos } \\
\text { Ogun }\end{array}$ & $\begin{array}{l}4.368900 \\
3.948060\end{array}$ \\
\hline 2004 & $\begin{array}{l}\text { Lagos } \\
\text { Ogun }\end{array}$ & $\begin{array}{l}4.741010 \\
4.038090\end{array}$ \\
\hline 2005 & $\begin{array}{l}\text { Ogun } \\
\text { Oyo }\end{array}$ & $\begin{array}{l}2.953070 \\
2.616970\end{array}$ \\
\hline 2006 & $\begin{array}{l}\text { Oyo } \\
\text { Lagos } \\
\text { Ogun }\end{array}$ & $\begin{array}{l}2.564130 \\
2.565340 \\
2.726550\end{array}$ \\
\hline 2007 & $\begin{array}{l}\text { Lagos } \\
\text { Ogun } \\
\text { Oyo }\end{array}$ & $\begin{array}{l}1.967480 \\
2.364280 \\
2.525350\end{array}$ \\
\hline
\end{tabular}

Note: ${ }^{\star}$ indicates all index values are significant at 0.05 significance level

All the years except 2006 had hotspots (Table 5). Like the RTAs, a southwest cluster of RTIs was noticed specifically in Oyo, Ogun, Lagos and Osun states, and this was clearly consistent in all the years except 2007.

Table 5. Hotspots for RTIs

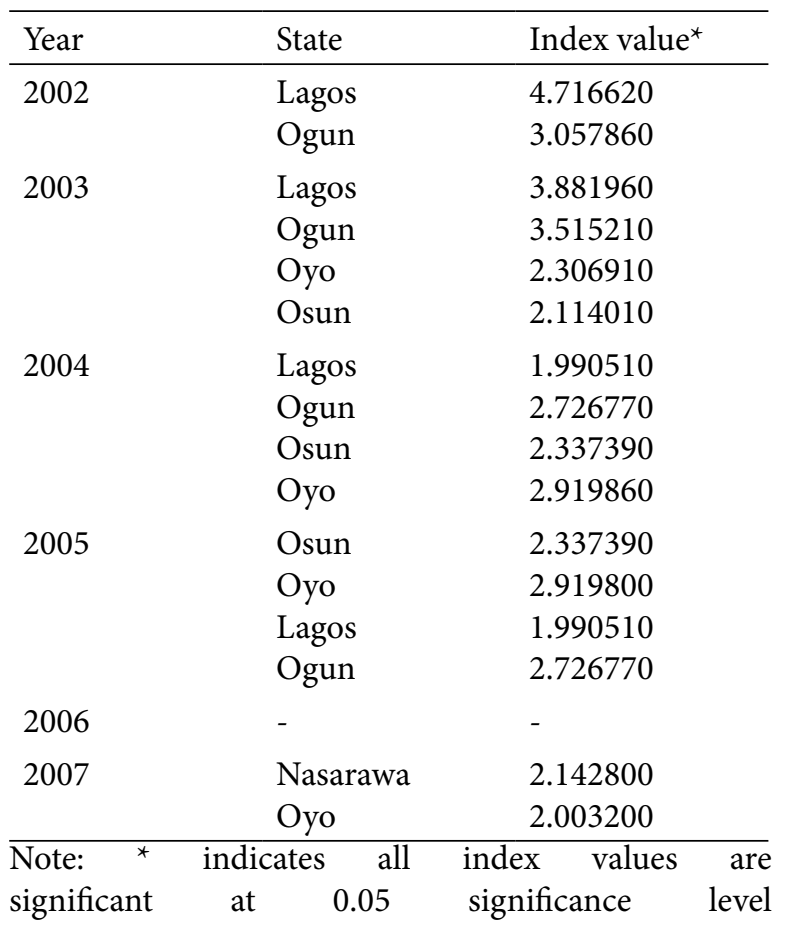


region could be one of the reasons for this hotspot. This highway among others has been described by some as a death trap [Okwuofu, 2011] because many lives have been lost and many people injured. To strengthen this point, a newspaper report pointed out that only fifteen percent (15\%) of the country's federal roads were good [Nwaneri, 2011]. In other words, a very large fraction of the federal road network is in bad shape. This probably explains why Nigeria was adjudged to be the 2nd worst country with the most unsafe roads [World Health Organisation, 2009].

Generally, Nigerian roads are in dreadful conditions because of "...continued lack of maintenance, poor design and construction, excessive use and inadequate financing of road projects by the federal, state and local governments" [Akinyemi, 2012]. Given these challenges, these roads repeatedly develop potholes and, in some cases, gullies which adversely affect traffic flow and possibly lead to accidents and fatalities. The poor road infrastructure factor is supported by Osayomi [2013]'s analysis of regional patterns of RTAs in Nigeria and has still proven to be a pervasive problem.

Another explanatory factor might be the relatively high vehicle ownership level in southwest Nigeria, which could translate to high accident severity and fatality rates in the region. Lagos state, for example, is arguably the state with the the highest motorisation rate in the country. The number of newly registered vehicles in 2000 was 32,041 and later increased to 229,879 in 2011 [Lagos State Government, 2012]. The likelihood of road accidents increases with more vehicles on the road. This absolutely agrees with prior studies which have indicated that road collisions were associated with increased ownership of vehicles [Vasconcellos, 1996; Jones et al. 2008; Kanchan et al. 2012].

Another reason could be the level of economic development. Accidents follow the pathways of economic development. Areas with high degree of economic activity are particularly known to draw people, goods and services from near and distant locations, thereby generating a high volume of vehicular traffic. In such circumstances, accidents are more likely to occur. For example, Lagos state which is popularly regarded as Nigeria's commercial capital, has the largest concentration of financial, manufacturing activities, and wholesale/retail trade institutions [United Nations Development Fund, 2009]. In addition, Lagos's international and domestic airports, and sea ports are the busiest in the country. Figures show that the passenger volume at the domestic and international airports in 2011 was 4,127,100 and 2,621,190 respectively. On the other hand, aircraft movement was estimated at 77,087 (Domestic) and 28,128 (International) at the end of 2011 [Federal Airports Authority of Nigeria, 2013]. Equally, Kano state, which has one of highest population density figures in the country, is the commercial and industrial hub of northern Nigeria with a large pool of textile, shoe and leather industries, just to mention a few. Besides, the state is noted for its fourth busiest international airport in the country (Aminu Kano International Airport). In 2011, its passenger traffic was 234,996 (Domestic) and 146,848 (International) [Federal Airports Authority of Nigeria, 2013]. No doubt, the volume of economic activity in such an area would certainly increase the risk of RTAs.

It is also a major transit point between other major urban centers in northern Nigeria. For instance, a federal highway connects Kaduna to Kano via Zaria. The Katsina-Maiduguri road passes through Kano. A rail line which originates from Lagos and goes through Kaduna, Zaria to Kano and ends in Nguru (Yobe state). These observations are comparable to the city of Afyonkarahisar, Turkey -which lies between major industrial centres, prominent tourist destinations and agrarian communities and which experienced in Turkey. This city experienced increased mobility and accidents when there was an influx of foreigners during the summer season [Erdogan et al. 2008]. This also agrees with Rosello and Saenz-de-Miera (2011) whose study considered the nexus between RTAs and tourism and found that increases in population due to increased tourist mobility resulted in the rise in RTAs in the popular Balearics Islands of Spain.

It must be highlighted that there are some limitations inherent in the study. Though the data were mainly derived from Nigeria's leading statistical agency, the authenticity of the data cannot be fully guaranteed. It is possible that these incidents were underreported or unreported in some states of the country, thus failing to provide the true accident figures, as it is common in many developing countries like Nigeria. The second limitation has to do with the unit of spatial analysis. This is important because scale is known to influence the spatial pattern of phenomena. A small area analysis would have been ideal for a study like ours because internal homogeneity is more common in smaller geographic areas than large ones. Unfortunately, data limitations at such scales limit our analysis. As it is, the state is the smallest area for which accident data are available.

It must be fully under stood that accidents are not only a result of regional factors like those highlighted above, but also the product of other risk factors which include the limited use of seat belt and safety helmets, mobile phones while driving, reckless and drunk driving, and the widespread use of unroadworthy vehicles in Nigeria.

\section{Conclusion}

In spite of all these limitations, this study prides itself in the examination of the spatio-temporal dynamics of RTAs in Nigeria. Besides strengthening the fact that RTAs, RTIs and RTDs are spatially heterogeneous, it has pointed out the presence of an accident belt in Nigeria. This definitely will trigger further investigation of underlying factors of this regional cluster and other isolated clusters. Information arising from further in- 
depth analysis would be helpful in the design of effective geographically variable accident prevention and control programmes. Overall, this is a departure from the consistent study of the ecological association between RTAs and risk factors that has been the dominant theme in the geographic study of RTAs in Nigeria.

Results from geospatial analysis have not only provided some insight in the understanding of the geographical distribution of RTAs, RTIs and RTDs in Nigeria but they have also opened up potential avenues for future inquiry. For instance, these results can generate hypotheses about spatial patterns and their associated determinants. More studies should consider the spatial pattern of RTAs, RTIs and RTDs at multiple scales ranging from the wards to senatorial districts. Further investigation is needed on the determining factors of the accident belt. The basic question to be asked is: 'What are the significant factors influencing the observed local spatial pattern of accidents?' More importantly, geospatial techniques have proved to be useful in evaluating the degree of spatial accident

\section{References}

Aderamo, A.J. (2012), Spatial Pattern of Road Traffic Accident Causalities in Nigeria. Mediterranean Journal of Social Sciences. 3(2) 61-71.

Akinyemi, Y.C. (2012), Road Transportation in Nigeria: Issues and Public Policy. Ibadan Journal of the Social Sciences. 19 (1) 16-30.

Andersson T.K. (2009), Kernel density estimation and $\mathrm{K}$ means clustering to profile road accidents hotspots. Accident Analysis and Prevention. Volume 41 3, 359-364

Atubi, A. O., and Onokala, P.C. (2009), Contemporary analysis of variability in road traffic accidents in Lagos State. African Geographical Review, 28, 11-41.

Chidoka, O. (2009), Welcome Address. FRSC Annual Inaugural Lecture Series. Annual Lectures Series Monograph 1. Federal Road Safety Commission. Accessed online www. frsc.gov.ng/frsccompendium.pdf

Djupken, R. (2010), Mapping the HIV/AIDS epidemic in Nigeria using exploratory spatial data analysis. GeoJournal 75(2):115. DOI: 10.1007/s10708-010-9350-1

Erdogan. S., Yilmaz, I; Baybura, T. and Gullu, M. (2008), Geographical information systems aided traffic accident analysis systems case study: city of Afyonkarahisar Accident Analysis and Prevention 40, 174-181.

Erdogan. S. (2009), Explorative spatial analysis of traffic accidents and road mortality among the provinces of Turkey. Journal of Safety Research. 40, 341-351.

Federal Airports Authority of Nigeria (2013), 2011- Annual Traffic Report. www.faannigeria/ statistics/2011-Annual\%20Traffic\%20Report. cluster and in identifying the location of significant spatial clusters. This, furthermore, has aided in the understanding of spatial patterns, which in turn, will help policy makers, road safety agencies and other stakeholders to create spatially sensitive accident prevention measures. Therefore, these GIS analytical tools can serve as tools of accident surveillance systems.

In view of the findings above, the study calls for immediate action to significantly reduce RTAs, RTIs and RTDs. To this end, we recommend the following: (i) zonal and sector commands of the Federal Road Safety Commission (FRSC) must design place-specific interventions such as deployment of more road safety officials, road safety campaigns, particularly in the accident belt, to reduce the accident, casualty and fatality rates on Nigerian roads. (ii) geographically variable emergency medical services should be made available in all the states to facilitate quick rescue operations (iii) Nigerian roads should be continually monitored and maintained (iv) strict enforcement of traffic regulations, use of safety belts and helmets is advised.

xls. Accessed online November 5th, 2013. Federal Road Safety Commission (FRSC). (2012), Sign up to decade of action. Available at: http:// www.frsc, gov.ng/sign-up-to-decade-of-action.

Gbadamosi, K. T. (2002), Traffic regulations and road traffic accidents in Nigeria A Spatial analysis (Unpublished $\mathrm{PhD}$ dissertation).Ibadan: University of Ibadan. Ipingbemi, O. and Dandy, O.A. (2011), The Burden of Hospitalization of Road Crash Victims in a Secondary Health Care Facility in Oyo, Nigeria. Ibadan Planning Journal 1(2), 127-136. Jegede, F. (1988), Spatial-temporal analysis of road traffic accidents in Oyo State, Nigeria. Accident Analysis and Prevention, 20, 227-243. Jones, A., Haynes, R., Kennedy, V., Harvey, I., Jewell, T., and Lea, D. (2008), Geographical variation in mortality and morbidity from road traffic accidents in England and Wales. Health and Place. 14, 519-535

Kanchan V. k., Bakkannavar, S. M., Kumar, N., and Unnikrishnan, B. (2012), Analysis of fatal road accident in a coastal township of South India. Journal of Forensic and Legal Medicine, doi/10.1016/j.jflm.2012,02.31

Lane, G.W. and Sui, D.Z. (2010), Geographies of identity theft in the U.S.: understanding spatial and demographic patterns, 2002-2006. GeoJournal Volume 75, Issue 1, pp 43-55 Loo, B.P.Y. (2013), Validating crash locations for quantitative spatial analysis: A GIS based approach. Accident Analysis and Prevention 38 (5) 876-886

Michmi, A. and Wimberly, M.C. (2010), Spatial patterns of obesity and associated risk factors in the coterminous US. American 
Journal of Preventive Medicine. 39 (2) 1-13

National Bureau of Statistics (2009), Annual Abstract of Statistics 2009. Abuja: National Bureau of Statistics

Nwaneri, N. (2011), Only 15\% of Nigerian roads in good shape. The Nation, August, 11, p.3.

Osayomi, T. (2013), Regional determinants of road traffic accidents in Nigeria: identifying risk areas in need of intervention. African Geographical Review. 32 1, 88-99.

Portnov, B.A, Barchana, M. and Dubnov, J. (2009), Exploratory analysis of potential risk factors of a rare disease: Spatial distribution of adrenocortical carcinoma in Israel as a case study. Science of the Total Environment. 407, 1738-1748.

Pulugurtha, S.S; Krishnakumr, V.K; and Nambisan, S.S. (2007), New methods to identify and rank high pedestrian crash zones: An Illustration. Accident Analysis and Prevention 39 (4) 800-811.

Rodriguez-Morales, B; Diaz_Varela, E.R and Marey-Perez, M.F (2013), Spatiotemporal analysis of vehicle collisons involving wild boar and roe deers in northwest Spain. Accident Analysis and Prevention 60, 121-133.

Rosello,J.and Saenz-de-Miera, O. (2011), Roadaccidents and tourism: The case of the Balearic Islands (Spain). Accident Analysis and Prevention. 43. 675-683.

Samuelsson, U. and Lofman, O. (2004), Geographical mapping of type 1 diabetes in children and adolescents in south east Sweden. Journal of Epidemiology and Community Health 58: 388-392.

Sharma, A. (2012), Exploratory spatial data analysis of older adult migration: A case study of North Carolina. Applied Geography. Volume 35 327-333

Vasconcellos, E. (1996), Reassessing traffic accidents in developing countries. Transport Policy, 2, 263-269.

World Health Organization (2009), Global status report on road on road safety: Time for action. Available at http://www.who.int/violence_ injury_prevvention/road_safety_status/2009

World Health Organization (2013), Global status report on road on road safety: Time for action. Available at: http://www.who.int/violence_ injury_prevvention/road_safety_status/2013 Yu, D. and Wei, Y.D. (2008), Spatial data analysis of regional development in Greater Beijing, China, in a GIS environment. Papers in Regional Science, Volume 87 Number 1, 97-117. 